Tate and May.

“Descriptions of New Genera and Species of Australian Mollusca": Trans. Roy. Soc. S. Austr., 1900, vol. xxir, pt. 2, pp. 90-103.

Tate and J. Dennant.

"Correlation of the Marine Tertiaries of Australia," pt. i: Trans. Roy. Soc. S. Austr., 1893, vol. xvii, pt. 1, pp. 203 226. Pt. ii: 'Trans. Roy. Soc. S. A ustr., 1895, vol. xix, pt. 2, pp. 108-121. Pt. iii : Trans. Roy. Soc. S. Austr., 1896, vol. xx, pt. 1, pp. 118-148.

TATE AND J. Brazier.

" Check List of the Fresh-water Shells of Australia" [1881]: Proc. Linn. Soc. New South Wales, 18s2, vol. vi, pp. $552-569$.

Tatr and J. S. HoLden.

"On the Iron Ores associated with the Basalts of the North-East of Ireland" [1869]: Quart. Journ. Geol. Soc, 1870, vol. xxvi, pp. 151-165.

TATE AND J. F. BLAKE.

"The Yorkshire Lias," pp. viii, 475 , xii ; 23 pls. (3 col.), 2 maps col. ; text illust. London, 1876.

Tate et alin.

" On the Occurrence of Glacial Boulders at Yellow Cliff, Crown Point Station, Finke Valley, Central Australia": Rep. Austr. Assoc., 1898 (1899), pp. 109-127.

\title{
JAMES SHIPMAN, F.G.S.
}

BORN APrIL 30, 1848.

Died November 21, 1901.

As energetic worker on geology has been lost to science in the death of Mr. James Shipman. In early life he was apprenticed to the printing trade; he subsequently entered the employment of the late Mr. Edmund Renals, then proprietor of the Nottingham Daily Express, and at the time of his death Mr. Shipman occupied a post on the sub-editorial staff. About the year 1868 he attended the science classes held by the late Edward Wilson, and in 1870 he won the bronze medal of the Science and Art Department for geology. Later on Mr. Shipman became a teacher in the science. $\mathrm{He}$ devoted himself with remarkable enthusiasm to the study of all the open geological sections in and around Nottingham, and furnished important aid to Mr. W. T. Aveline when he was revising the geological survey map of the district. He became an active member of the Nottingham Naturalists Society, contributing to its Transactions papers on the greology of various parts of Nottinghamshire and Derbyshire. The Drift deposits, the New Red Rocks, and the Coal-measures naturally attracted his chief attention, and so thoroughly sound was his knowledge that his advice was sought in various inquiries of economic importance. As a journalist his time was greatly occupied, and especially at night, so that it was only in leisure hours, often taken from those which should have been devoted to sleep, that he was enabled to give so much time to his favourite subject. In 1887 he published "Holiday Notes of a Geologist," a work which contained many interesting reminiscences. There can, however, be little doubt that by utilizing what he termed his 'free' days so fully, while labouring also at night, he too severely taxed his strength. He died suddenly at the age of 53. ${ }^{2}$

1 We are indebted for most of the above particulars to an article by Mr. A. Stapleton in the Nottingham Daily Express. 